DOI: https://doi.org/10.34287/MMT.2(49).2021.1

O. S. Troyan, O. A. Levada

State Institution «Zaporizhzhia Medical Academy of post-graduate education Ministry of Health of Ukraine» Zaporizhzhia, Ukraine

О.С. Троян, О. А.Левада

Державний заклад «Запорізька медична акаделія післядипломної освіти Міністерства охорони здоров'я України» Запоріжж, Украӥна

\title{
AGE-ADJUSTED NORMATIVE DATA AND DISCRIMINATIVE VALIDITY OF COGNITIVE TESTS IN THE UKRAINIAN ADULT PATIENTS WITH MAJOR DEPRESSIVE DISORDER
}

\author{
Вікові нормативні дані та дискримінаційна вамідність \\ когнітивних тестів в украӥнсыкій когорті дорослих паџієнтів \\ 3 великим депресивним розАадом
}

\begin{abstract}
Purpose of the study. We aimed: 1 ) to compare cognitive functioning in patients with major depressive disorder (MDD) and healthy controls (HC) in the Ukrainian adult population by the results of neuropsychological assessment, that included Perceived Deficit Questionnaire (PDQ-5), Rey Auditory Verbal Learning Test (RAVLT), Trail Making Test Part B (TMT-B), Digit Symbol Substitution Test (DSST); 2) to obtain ageadjusted normative data of RAVLT, TMT-B, and DSST tests; 3 ) to explore the diagnostic utility of PDQ-5, RAVLT, TMT-B, and DSST tests to separate patients with $M D D$ from $H C ; 4)$ to provide cutoff scores of the PDQ-5, RAVLT, TMT-B, and DSST tests, stratified by age, that discriminate $M D D$ patients from $\mathrm{HC}$, based on the sensitivity ( $\mathrm{Se}$ ) and specificity ( $S p)$ of the obtained scores.

Materials and methods. $130 \mathrm{MDD}$ medicationfree patients (according to DSM-5) and $70 \mathrm{HC}$ were enrolled in the study. Psychopathological (by Montgomery-Asberg Depression Rating Scale (MADRS ) and Clinical Global Impression Severity (CGI-S)) and neuropsychological (by PDQ-5, RAVLT, TMT-B, DSST) parameters were analyzed in all subjects. To assess between-group differences parametric and non-parametric tests were used (T-test, Mann-Whitney test, chi-squared test). Areas under the curve (AUC) of receiver operating characteristic ( $R O C$ ) were calculated to determine if the results of $P D Q-5, R A V L T, T M T-B$, and

Peфepam

Мета дослідження. Ми лили на леті: 1) порівняти когнітивне функціонування пацієнтів з великил депресивнил розладол (ВДР) та осіб групи здорового контролю (ГК) в украӥнській когорті людей дорослого віку за результатали нейропсихологічної оцінки, яка включала опитувальник суб'єктивного когнітивного дефіциту (Perceived Deficit Questionnaire - PDQ-5), mecm Рея на слухове запал'ятовування вербальной інфорлаиї̈ (Rey Auditory Verbal Learning Test RAVLT), тест послідовних з'єднань, частина $B$ (Trail Making Test Part B TMT-B), mecm заліни символів иифрали (Digit Symbol Substitution Test - DSST); 2) отрилати норлативні дані тестів RAVLT, TMT-B та DSST з урахуванням віку; 3 ) дослідити діагностичну иінність тестів PDQ-5, RAVLT, TMT-B та DSST для відокреллення пацієнтів з ВДР від ГК; 4) отрилати граничні показники тестів PDQ-5, RAVLT, TMT-B та DSST, стратифіковані за вікол, які з оптимальною чутливістю (Se) та специфічністю ( $\mathrm{Sp}$ ) відділяли пацієнтів із ВДР від ГК.

Матеріали та методи. В дослідження було залучено 130 пацієнтів з ВДР (згідно з критеріяли DSM-5), що не прийлали фарлакотерапію та 70 осіб ГК. У всіх учасників були проаналізовані психопатологічні (за шкалали депресії Монтголері-Асберг (MADRS) та загальної клінічної оиінки (CGIS)) та нейропсихологічні (за PDQ-5, RAVLT, TMT-B, DSST) паралетри. Для оцінки 
DSST tests performance could discriminate $M D D$ patients from HC. Cutoff scores, which separated $M D D$ patients from $H C$ with empirical optimal $S e$ and $S p$, were derived from the ROC curves. The statistical threshold was set at $p<0.05$.

Results. Surveyed groups were comparable in age, gender, and level of education. Besides the expected statistical difference in MDD patients and HC on MADRS and CGI-S scores, sufficient distinction in neuropsychological test performance was found between the comparison groups. MDD participants were significantly worse $(p<0,0001)$ in subjective ( $P D Q-5)$ as well as objective cognitive functioning (RAVLT subtests, DSST, TMT-B scores). Significant differences between MDD and $H C$ groups, established during objective cognitive testing, were specific to each age group, despite the general trend of deterioration of cognitive performance with age. ROC analysis was used to examine the utility of PDQ-5, RAVLT, TMT-B, and DSST tests to discriminate $M D D$ patients from HC. AUC-ROCs showed that all cognitive measures included in this study adequately differentiated between the performance of HC and MDD patients. We also provided cutoff scores for five age groups in discriminating $M D D$ patients from $\mathrm{HC}$, based on the Se and Sp of the prescribed scores. The age ranges for each group were as follows: Group 1-18-24 years; Group 2 - 25-34 years; Group 3 - 35-44 years; Group 4-45-54 years; Group 5-55-65 years. For PDQ-5 cutoff scores were: in the whole sample $>3,5$ points ( $\mathrm{Se}$ 90\%, Sp 91\%); Group $1>3,5$ points ( Se 100\%, Sp $83 \%$ ); Group $2>3,5$ points ( Se 93\%, Sp 89\%); Group $3>2,5$ points (Se 89\%, Sp 83\%); Group $4>2,5$ points ( Se 100\%, Sp 84\%); Group $5>3,0$ points (Se $90 \%$, Sp 100\%). For immediate recall of the RAVLT cutoff scores were: in the whole sample < 56,5 words ( Se 85\%, Sp 82\%); Group $1<57$ words (Se 100\%, Sp 73\%); Group 2 $<59,5$ words (Se 85\%, Sp 70\%); Group $3<59,5$ words (Se 91\%, Sp 83\%); Group $4<57,5$ words ( $\mathrm{Se} 86 \%$, Sp 74\%); Group $5<53,5$ words ( $\mathrm{Se} 94 \%$, Sp $80 \%)$. For proactive interference of the RAVLT cutoff scores were: in the whole sample $<6,5$ words (Se 66\%, Sp 72\%); Group $2<7,5$ words (Se 83\%, Sp 63\%); Group $3<6,5$ words ( $\mathrm{Se} 70 \%$, Sp 75\%); Group 4<6,5 words (Se 72\%, Sp 74\%); an unsatisfactory quality of the models for groups 1 and 5 did not allow to determine the cutoff scores for these age groups. For retroactive interference of the RAVLT cutoff scores were: in the whole sample < 13,5 words (Se 86\%, Sp 76\%); Group $2<13,5$ words ( $\mathrm{Se} 85 \%$, Sp 89\%); Group $3<13,5$ words ( $\mathrm{Se} 82 \%$, Sp 92\%); Group $4<13.5$ words ( $\mathrm{Se} 82 \%$, Sp 74\%); Group $5<12,5$ words (Se 94\%, Sp 80\%); Group 1 had an unsatisfactory quality of the model. For TMT-B cutoff scores were: in the whole sample $>63 \mathrm{~s}$ ( Se 70\%, Sp 68\%); Group $1>61 \mathrm{~s}$ ( Se 91\%, Sp 64\%); Group $2>58,5$ s (Se 73\%, Sp 60\%); Group 3>58,0 s (Se 83\%, Sp 83\%); Group $5>71,5 \mathrm{~s}$ міжгрупових відлінностей використовували параметричні та непараметричні статистичнi mecmu (T-test, Mann-Whitney test, chi-squared test). Площі під кривою (AUC) receiver operating characteristic (ROC) були розраховані, щоб визначити, чи ложуть результати тестів PDQ-5, RAVLT, TMT-B, DSST дискрилінувати хворих з ВДР віә ГК. 3 ROC кривих були визначені граничні показники когнітивних тестів, що з оптилальною Se ma Sp відокреллювали паиієнтів із ВДР від ГК. Статистичний поріг був встановлений на рівні $p<0,05$.

Результати. Групи порівняння достовірно не відрізнялись за віком, статтю та рівнем освіти. Окріл очікуваної статистичної різниці між групали ВДР та ГК за загальнили балали MADRS ma CGIS, виявлена значуща різниця в когнітивнолу функціонуванні за опитувальникол PDQ-5, а також за об’єктивнил нейропсихологічнил тестуваннял (RAVLT, TMT-B та DSST). Пацієнти з ВДР у порівнянні з особали ГК лиали значно гірші результати тесту RAVLT (субтести на негайне пригадування, проактивну та ретроактивну інтерферениію), TMT-B та DSST. Cуттеві відлінності ліж групали ВДР та ГК, виявлені під час виконання об'єктивних когнітивних тестів, зберігались для кожної вікової категорї̈, незважаючи на загальну тенденцію погіршення когнітивних показників з вікол. ROC-аналіз був використаний для вивчення діагностичної иінності тестів PDQ-5, RAVLT, TMT-B, DSST для розрізнення пацієнтів з ВДР від ГК. AUC-ROCs проделонстрували, що всі когнітивні тести, включені у ие дослідження, мали відлінну або дуже гарну або гарну якість лоделі для відмежування пацієнтів з ВДР від ГК. Також були отрилані граничні результати тестів $P D Q-5$, RAVLT, TMT-B, DSST з оптилальнили значенняли Se та Sp для дискрилінації хворих з ВДР від ГК у п'яти вікових групах. Вікові діапазони для кожної групи були наступнили: 1 група - 18-24 роки; 2 група - 25-34 роки; 3 група - 35-44 роки; 4 група - 45-54 роки; 5 група - 55-65 років. Граничні показники для $P D Q-5$ були: у всій вибіриі > 3,5 балів (Se 90\%, Sp 91\%); 1 груni > 3,5 балів (Se 100\%, Sp 83\%); 2 групi $>$ 3,5 балів ( $S$ е 93\%, Sp 89\% ); 3 групi > 2,5 балів ( $\mathrm{Se} 89 \%, \mathrm{Sp} 83 \%$ ); 4 групi > 2,5 балів (Se 100\%, Sp 84\%); 5 групi > 3,0 балів ( $S$ е 90\%, Sp 100\%). Граничні показники для субтесту RAVLT на негайне пригадування: у всій вибіриі $<56,5$ слів ( $\mathrm{Se} 85 \%$, Sp 82\%); 1 групi < 57 слів (Se 100\%, Sp 73\%); 2 груni < 59,5 слів ( Se 85\%, Sp 70\%); 3 групi < 59,5 слів (Se 91\%, Sp 83\%); 4 групі $<57,5$ слів (Se 86\%, Sp 74\%); 5 групі $<53,5$ слів (Se 94\%, Sp 80\%). Граничні показники для субтесту RAVLT на проактивну інтерференцію: у всій вибіриі <6,5 слів ( $\mathrm{Se} 66 \%, \mathrm{Sp} 72 \%$ ); 2 групi $<7,5$ слів (Se 83\%, Sp 63\%); 3 групi 
( Se 90\%, Sp 80\%); Group 4 had an unsatisfactory quality of the model. For DSST cutoff scores were: in the whole sample $<58.5$ points ( Se $74 \%$, Sp 63\%); Group $2<59,5$ points (Se 71\%, Sp 67\%); Group $3<60,5$ points (Se 78\%, Sp 83\%); Group 4 $<53,5$ points ( $S$ e $68 \%$, Sp 72\%); groups 1 and 5 had an unsatisfactory quality of the model.

Conclusions. Patients with an active episode of MDD demonstrate as subjective as objective cognitive impairments as compared to HC. Cognitive dysfunction in the Ukrainian cohort of MDDpatients is characterized by mild impairments in working memory; moderate impairments in alternating attention; and moderate impairments in executive functioning. $P D Q-5$ and neuropsychological tests, such as RAVLT (subtests for immediate recall, proactive and retroactive interference), TMT-B, and DSST show from excellent to good diagnostic value for separating patients with $M D D$ from $H C$. PDQ-5, RAVLT, TMT-B, and DSST and obtained age-adjusted cutoffs of those tests could be used by clinicians in everyday practice as a method to secure a more valid assessment of cognitive function in MDD patients.

Keywords: Major depressive disorder; cognitions; PDQ-5; RAVLT; DSST; TMT-B.
$<6,5$ слів (Se 70\%, Sp 75\%); 4 групi $<6,5$ слів (Se 72\%, Sp 74\%); незадовільна якість моделей для груп 1 та 5 не дозволила визначити граничні показники виконання субтесту для иих вікових груп. Граничні показники для субтесту RAVLT на проактивну інтерферениію: у всій вибіриі $<13,5$ слів (Se 86\%, Sp 76\%); 2 групi < 13,5 слів ( $\mathrm{Se} 85 \%$, Sp 89\% ); 3 групi $<13,5$ слів ( $\mathrm{Se} 82 \%$, Sp 92\% ); 4 групi $<13,5$ слів (Se 82\%, Sp 74\%); 5 групi $<12,5$ слів ( $\mathrm{Se} 94 \%, \mathrm{Sp} \mathrm{80 \% );} 1$ група мала незадовільну якість лоделі. Граничні показники для TMT-B: у всій вибіриі > 63 c (Se 70\%, Sp 68\%); 1 групі $>61$ c (Se 91\%, Sp 64\%); 2 гpyni > 58,5 c (Se 73\%, Sp 60\% ); 3 гpyni > 58,0 c ( Se 83\%, Sp 83\%); 5 гpyni > 71,5 с (Se 90\%, Sp 80\%); 4 група мала незадовільну якість моделі. Граничні показники для DSST: у всій вибіриі < 58,5 (Se 74\%, Sp 63\%); 2 әрyni $<59,5$ (Se 71\%, Sp 67\%); 3 гpyni $<60,5$ ( Se 78\%, Sp 83\%); 4 грyni <53,5 (Se 68\%, Sp 72\%); групи 1 і 5 лали незадовільну якість моделі.

Висновок. Пацієнти з активнил епізодол ВДР в порівнянні з ГК мають як суб'єктивні, так і об'єктивні когнітивні порушення. Когнітивна дисфункиія в украӥнській когорті хворих на ВДР характеризується легкили порушенняли робочої пам'яті; полірними порушенняли уваги; та полірнили порушенняли виконавчих функиій. Опитувальник $P D Q-5$ та нейропсихологічні тести, такі як RAVLT (субтести на негайне пригадування, проактивну та ретроактивну інтерференцію), TMT-B та DSST лають від відлінної до гарної діагностичну иінність для відокреллення пацієнтів з ВДР віо ГК. Тести PDQ-5, RAVLT, TMT-B та DSST та отрилані з урахуваннял віку граничні показники иих тестів можуть бути використані клініцистами у повсякденній практиці як метод, що забезпечує більш достовірну оцінку когнітивних функиій у пацієнтів із ВДР.

Ключові слова: великий депресивний розлад; когнітивні функиї; PDQ-5; RAVLT; DSST; TMT-B.

\section{INTRODUCTION}

Major Depressive Disorder (MDD) is one of the most important theoretical and applied problems of modern psychiatry, given its prevalence and socioeconomic implications [1]. MDD ranks second in the structure of mental disorders, and the socioeconomic burden caused by it is largely related to the loss or decline in productivity of affected individuals [2, 3]. The need to restore the functioning of patients with MDD in the workplace, society, and family encourages the search for factors that negatively affect it. Among them, cognitive dysfunction occupies a prominent place, which, along with affective and somatic symptoms, is a structural part of the clinical picture of MDD [4].
Cognitive dysfunction in affective disorders hasn't been studied much until the last two decades, although cognitive impairments are widespread in patients with MDD. They are found in $94 \%$ of patients with an acute depressive episode (DE) and $44 \%$ of patients with symptomatic remission [5]. It is proved that cognitive impairments directly affect the work productivity and social functioning of patients and impede functional recovery [6, 7, 8, 9]. Nevertheless, only $38 \%$ of psychiatrists in their daily practice use cognitive instruments to screen patients; of these, only $3 \%$ were actually appropriate for use in MDD [10]. Therefore, there is a need for a standardized method for evaluating cognitive dysfunction.

It is now known that from clinical and phenomenological points of view, cognitive 
deficits in MDD are mainly manifested in the domains of memory [K. Hinkelmann et al., 2012], executive functions, attention and psychomotor speed $[12,13,14]$. At the same time, there is ample evidence of the cultural specificity of neuropsychological disorders, which is found in ongoing research in different countries [15-19]. Studies of the specifics of cognitive impairment in MDD in the Ukrainian patient population are absent.

An applied task is the validation of diagnostic tools for cognitive dysfunction of the Western neuropsychology (Perceived Deficit Questionnaire PDQ-5, Rey Auditory Verbal Learning Test RAVLT, Trail Making Test Part B TMT-B, Digit Symbol Substitution Test DSST) in the Ukrainian cohort of patients with MDD to objectify cognitive deficit. Solving this problem will significantly improve the diagnosis of cognitive deficits in persons with MDD in the daily practice of Ukrainian psychiatrists.

Taking into account the considerations outlined above, the objectives of our study were: 1) to compare cognitive functioning in MDD patients and healthy controls in the Ukrainian population by the results of PDQ-5, RAVLT, TMT-B, and DSST; 2) to obtain age-adjusted normative data of RAVLT, TMT-B, and DSST tests for adults; 3) to explore the diagnostic utility of these tests to separate patients with MDD from HC; 4) to provide cutoff scores of the tests, stratified by age, that discriminate cognitively $\mathrm{HC}$ from MDD patients, based on the sensitivity and specificity of the obtained scores.

\section{MATERIALS AND METHODS}

Study design. This was a case-control study, which included 205 participants aged 18 to 65 years. Outpatients $(\mathrm{n}=130)$ with MDD diagnosis according to DSM-5 criteria [20] were recruited through Zaporizhzhia Regional Clinical Psychiatric Hospital, Ukraine. Eligibility criteria for the study participants were described elsewhere [21]. Before entering the study, all patients had received no actual antidepressant medication. Subjects were excluded if they had any other psychiatric diagnosis, high suicidal risk, substance dependence/abuse over the past year, significant neurological disorders, head trauma, unstable medical conditions, history of endocrine diseases, psychotic symptoms, the risk for the hypomanic switch [21]. Seventy-five healthy controls (HC) with no current psychiatric disorder were enrolled within the same period that the MDD patients were included. HC were excluded based on the use of medications and/or illicit drugs; the intake of alcohol within 48 hours of the study visit; and the presence of an unstable medical condition, which could affect cognitive function [21].

The study was approved by the local ethics committee and performed following the ethical standards laid down in the 1964 Declaration of Helsinki and its later amendments and registered at ClinicalTrials.gov (NCT03187093). All participants gave written informed consent after study procedures were explained and before participation.

Clinical Assessments. Depression severity was evaluated using Montgomery-Asberg Depression Rating Scale (MADRS) [22] and Clinical Global Impression Severity (CGI-S) scale [23]. Assessment of the severity of depression according to MADRS was as follows: 0-11 points - no depression, $12-23$ points - mild depression, 24-34 points - moderate depression, 35-60 points severe depression [22]. An integrative assessment of the severity of the patien`s condition was done using a subscale "Severity" of the CGI [23]. CGI-S score is based on the general clinical experience of a physician regarding a specific population of patients. The severity of the patient's condition over the past seven days on the CGI-S subscale was graded as follows: 1 - normal; 2 - borderline mentally ill; 3 - mildly ill; 4 - moderately ill; 5 - markedly ill; 6 - severely ill; 7 - among the most extremely ill patients.

Neuropsychological Assessments. Patients subjective cognitive functioning was assessed using the Ukrainian version of PDQ-5, a validated 5-item self-report scale measuring perceived difficulties in executive functioning, concentration, and memory, ranging from 0 to 4 (table 1) [24]. The questionnaire estimates subjective symptoms over the past week and its total score ranges from 0 to 20 , with higher scores reflecting greater severity.

The objective neuropsychological investigation included several tests that proved their validity concerning quantitative and qualitative parameters of cognitive deficits in patients with MDD: RAVLT; TMT-B; and DSST [8, 25, 26]. The tests were administered using paper and pencil.

RAVLT is used to analyze verbal learning and memory, including immediate memory, retroactive and proactive interference effects, and encoding versus retrieval. In our study, we administered Ukrainian translation of the World Health Organization/University of California Los Angeles version of the RAVLT (table 2) [27]. The test consists of two lists (A and B), containing 15 words each. All test words were selected from five categories and included three examples for a separate category. The words of List A are read with a one-second interval between words for five consecutive trials, each trial is followed by a free-recall. The total number of words across the five trials is defined as an immediate recall. On completion of Trial 5, an interference list of 15 new words (List B) is presented, followed by a free-recall test of that list - to assess proactive 
interference. Immediately after this, delayed recall of the List A is tested without further presentation of the words - to assess retroactive interference. After a 30-minute delay period, the examinee is again required to recall the words from List $\mathrm{A}$ - to evaluate delayed recall. Finally, a list with 30 words is presented, which includes those from List A and 15 new items, and the person has to identify the words from List A - to assess recognition.

Ukrainian version of Perceived Deficit Questionnaire 5 (PDQ-5)

\begin{tabular}{|c|c|c|c|c|c|}
\hline How often in the last 7 days... & $\begin{array}{l}\dot{0} \\
\dot{0} \\
z\end{array}$ & 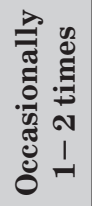 & 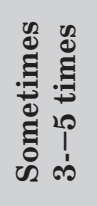 & $\stackrel{\overrightarrow{0}}{\overrightarrow{0}}$ & 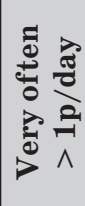 \\
\hline You had difficulty planning things? & 0 & 1 & 2 & 3 & 4 \\
\hline Was it difficult for you to concentrate on what you were reading? & 0 & 1 & 2 & 3 & 4 \\
\hline You forgot what number it was today until you checked it out? & 0 & 1 & 2 & 3 & 4 \\
\hline After talking on the phone, you forgot what you were talking about? & 0 & 1 & 2 & 3 & 4 \\
\hline You suddenly notice that you don't think about anything? & 0 & 1 & 2 & 3 & 4 \\
\hline
\end{tabular}

Ukrainian translation of RAVLT

\begin{tabular}{|l|c|c|c|}
\hline \multicolumn{1}{|c|}{ List A } & List B & List of words for recognition \\
\hline Shoulder & Boot & Airror & Lose \\
\hline Cat & Monkey & Than \\
\hline Ax & Bowl & Candle & Shoulder \\
\hline Bed & Cow & Motorcycle & Nose \\
\hline Plane & Finger & Hammer & Truck \\
\hline Ear & Dress & Watch & Eye \\
\hline Dog & Spider & Chair & Fish \\
\hline Hammer & Cup & Plane & Bike \\
\hline Chair & Bee & Turtle & Snake \\
\hline Auto & Leg & Horse & Bench \\
\hline Eye & Hat & Leg & Bus \\
\hline Horse & Hat & dog & Bed \\
\hline Than & Kettle & Table & Auto \\
\hline Watch & Mouse & Cat & \\
\hline Bike & Hand & & Sur \\
\hline
\end{tabular}

TMT-B allows detecting violations of information processing speed, switching attention, and executive functions [25]. To perform the test, a patient is provided with a drawing with circles with inscribed numbers from 1 to 12 and letters of the alphabet from A to L (fig. 1a). The TMT-B requires to connect alternately numbers and letters in ascending order (1 A, 2B...12L). During the test, the researcher immediately points out errors, and the participant needs to correct them before proceeding. The faster the test is passed, the better. Criteria for assessing the performance of the test are as follows: $0-60 \mathrm{~s}-$ excellent; $61-72 \mathrm{~s}-$ normal; 73-105 s - violation of moderate severity; $\geq 106 \mathrm{~s}-$ severe cognitive impairment [28]. In this interpretation of the test, the patient's age is not taken into account.

The DSST test was used to assess executive functions, information processing speed, memory, concentration, and switching attention. During the test, the participant has to copy in the spaces below the lines of numbers the characters that correspond to each digit according to the key located at the top of the page (fig. 1b) [25]. The overall score is the number of correct characters over 90 seconds.

Statistical analyses. Statistical analyses were carried out using SPSS Statistics (IBM) v.20.0. The results were presented as median (interquartile range) or means (SDs) or percentages. The statistical significance of between-group comparisons was 
determined using nonparametric and parametric criteria when appropriate (Mann-Whitney test, chi-squared test, T-test). Thereafter, the receiver operating characteristic (ROC) analysis was performed to build ROC curves for cognitive tests to determine their diagnostic value to discriminate patients with MDD from HC. A ROC-curve shows the level of sensitivity and specificity for each possible threshold value and allows to display the dependence of the number of truly positive results from false positives. The areas under the curves (AUC), their standard errors, and the 95\% confidence intervals for each cognitive test were calculated. The larger the area between the curves, the higher the sensitivity and specificity of the test, i.e. it is more accurate. In an ideal test, the curve passes through the upper left or lower right corner, indicating that the proportion of true positive test results is approaching $100 \%$. AUC is used to quantify the clinical significance of the test. The quality of the test can be judged on an expert scale for AUC values: 0,9-1,0 - excellent quality of the model; $0,8-0,9$ - very good quality; $0,7-0,8-$ good quality; $0,6-0,7-$ average quality; 0,5-0,6 - unsatisfactory quality. Cutoff scores with empirical optimal sensitivity and specificity were derived from the ROC curves. The statistical threshold was set at $\mathrm{p}<0,05$.

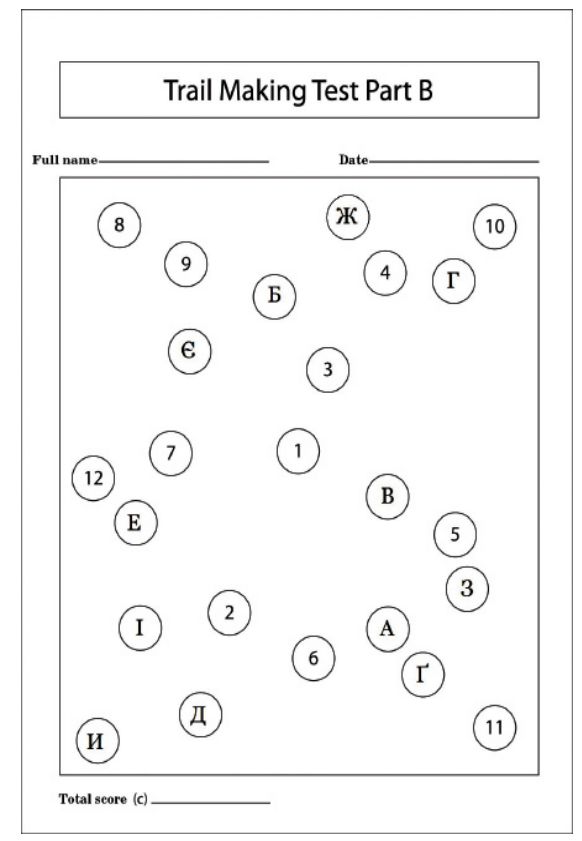

a
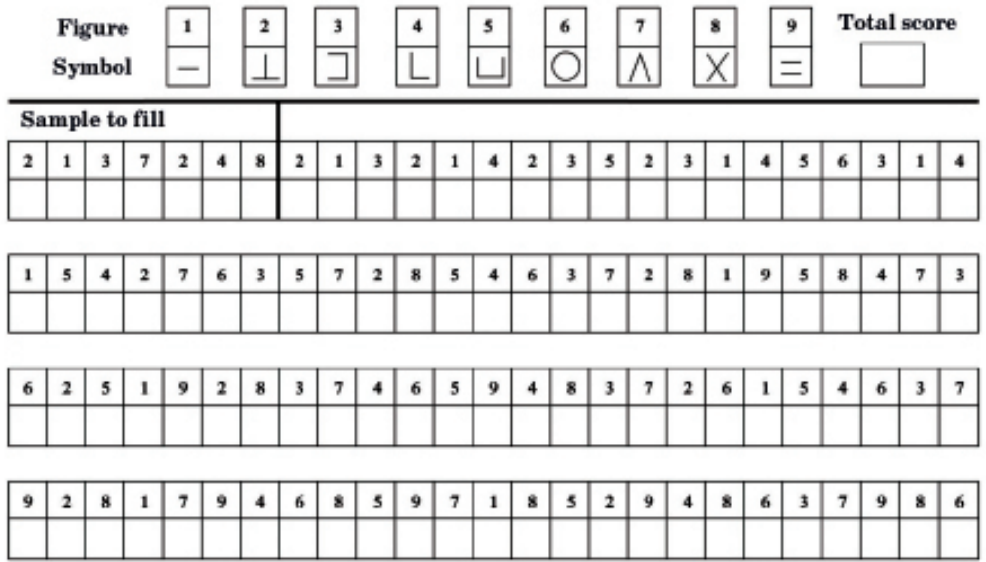

$\mathrm{b}$

Figure 1. Ukrainian variants of TMT-B (a) and DSST (b) tests

\section{RESULTS AND DISCUSSION}

Table 1 demonstrates the main demographic and neuropsychological characteristics of MDD and HC groups. Surveyed cohorts were comparable in age, gender, and level of education. The mean years of education in MDD patients and HC was about 15 years. The severity of depression (according to MADRS and CGI-S) was significantly more prominent in MDD patients than in HC.

Besides the expected statistical difference in MDD patients and HC on MADRS and CGIS total scores, a significant distinction in cognitive functioning was found when assessed subjectively (PDQ-5) as well as objectively by neuropsychological testing (RAVLT, TMT-B, and DSST) (table 3). Significant differences were obtained between the comparison groups when examining different aspects of memory using the RAVLT test. It was found that MDD patients performed significantly worse on subtests for immediate recall, proactive and retroactive interference, which indicated the presence of memory problems. In terms of severity, these violations were mild according to the metanorms of the test [29]. At the same time, the indicators of long-term memory (delayed recall and delayed recognition of verbal information) in the MDD group were normal according to Schmidt et al., although lower than in the HC [29]. Thus, the dysmnestic syndrome in patients with MDD was characterized by mild impairments of working memory while maintaining its long-term performance. These violations were also confirmed by subjective patients`assessment of the presence of cognitive symptoms (subscales "forget the current date" and "forget the phone call conversation" of PDQ-5). Our results on verbal memory have some discrepancies with the meta-analytical data of Ahern et al., who also did not find impairments in delayed recognition of verbal information in 
patients with MDD, but showed only a tendency to small disturbances in immediate recall and minor significant disturbances in delayed recall (in our study, patients also significantly differed from healthy individuals in this indicator, but their results corresponded to the normative data) [30].

Table 3

Demographic and clinical characteristics of comparison groups

\begin{tabular}{|c|c|c|c|}
\hline & $\begin{array}{c}\text { MDD } \\
\mathbf{n}=130\end{array}$ & $\begin{array}{c}\mathrm{HC} \\
\mathrm{n}=75\end{array}$ & $\mathbf{p}$ \\
\hline \multicolumn{4}{|l|}{ Demographic characteristics } \\
\hline Women, n (\%) & $88(68,3)$ & $44(56,3)$ & $0,19^{\mathrm{a}}$ \\
\hline Age, years* & $38,7(11,9)$ & $37,5(12,1)$ & $0,47^{\mathrm{b}}$ \\
\hline Education, years* & $14,6(2,0)$ & $15,0(1,6)$ & $0,10^{\mathrm{b}}$ \\
\hline \multicolumn{4}{|l|}{ Clinical assessments } \\
\hline \multicolumn{4}{|l|}{ Mood symptoms } \\
\hline MADRS total score $(0-60)$ & $28(22-33)$ & $3(0-5)$ & $<0,0001^{\mathrm{c}}$ \\
\hline CGI-S score & $4(4-5)$ & $1(1-1)$ & $<0,0001^{\mathrm{c}}$ \\
\hline \multicolumn{4}{|l|}{ Patient-reported cognitive symptoms } \\
\hline PDQ-5 total score $(0-20)$ & $8(5-11)$ & $1(0-2)$ & $<0,0001^{\mathrm{c}}$ \\
\hline MADRS «concentration difficulties» $(0-6)$ & $4(3-4)$ & $0(0-1)$ & $<0,0001^{\mathrm{c}}$ \\
\hline PDQ-5 «have trouble getting things organized» $(0-4)$ & $2(1-3)$ & $0(0-1)$ & $<0,0001^{\mathrm{c}}$ \\
\hline PDQ-5 «have trouble concentrating on what you were reading» $(0-4)$ & $2(1-3)$ & $0(0-1)$ & $<0,0001^{\mathrm{c}}$ \\
\hline PDQ-5 «forget the date unless you looked it up» $(0-4)$ & $2(1-3)$ & $0(0-1)$ & $<0,0001^{\mathrm{c}}$ \\
\hline PDQ-5 «forget what you talked about after a telephone conversation» $(0-4)$ & $1(0-2)$ & $0(0-0)$ & $<0,0001^{\mathrm{c}}$ \\
\hline PDQ-5 «fell like your mind went totally blank» $(0-4)$ & $0(0-2)$ & $0(0-0)$ & $<0,0001^{\mathrm{c}}$ \\
\hline \multicolumn{4}{|l|}{ Performance-based cognition } \\
\hline RAVLT immediate recall total score, number of words $(0-75)$ & $49(44-55)$ & $63(58-68)$ & $<0,0001^{\mathrm{c}}$ \\
\hline RAVLT proactive interference score, number of words $(0-15)$ & $6(5-7)$ & $8(6-9)$ & $<0,0001^{\mathrm{c}}$ \\
\hline RAVLT retroactive interference score, number of words $(0-15)$ & $11(9-13)$ & $15(14-15)$ & $<0,0001^{\mathrm{c}}$ \\
\hline RAVLT delayed recall score, number of words $(0-15)$ & $11(9-13)$ & $15(13-15)$ & $<0,0001^{\mathrm{c}}$ \\
\hline RAVLT delayed recognition score, number of words $(0-15)$ & $15(14-15)$ & $15(15-15)$ & $<0,0001^{\mathrm{c}}$ \\
\hline TMT-B, number of seconds & $74(60-90)$ & $58(43-68)$ & $<0,0001^{\mathrm{c}}$ \\
\hline DSST, number of correct symbols & $51(43-59)$ & $62(54-68)$ & $<0,0001^{\mathrm{c}}$ \\
\hline
\end{tabular}

Note: data are presented as median (upper-lower quartile) unless otherwise stated; * data are presented as means (SD); a Chi-square test; $b$ T-test for independent samples; c Mann-Whitney U-test

The TMT-B test was used to assess alternating attention. The test revealed significant differences between groups of patients and healthy individuals. It was found that the average time spent on the test was significantly higher in the group of patients with MDD compared with HC (table 3). According to the normative data of the authors of the test, attention disorders in patients with MDD were on average moderate in severity, while HC performed tasks at an excellent level [28]. Impairments in attention in patients with current DE were assessed on average as moderate by the researcher (the MADRS item «concentration difficulties»), as well as by the patients themselves (relevant item of $\mathrm{PDQ}-5$ ). Similar cognitive impairments on the TMT-B test were found in a general cohort of patients with MDD in recent studies and two meta-analyses, as well as in the elderly with MDD [12, 30, 31, 32, 33, 34].

The DSST test was used to objectively assess executive functions. The results of its completion in the comparison groups had statistically significant differences. Thus, patients with MDD reproduced significantly fewer symbols in the allotted period than those examined with HC. The degree of executive dysfunction in patients with MDD was on average moderate according to current standards [35] in contrast to healthy individuals, who have no executive dysfunction. This generally correlated with patients` subjective perceptions of their performance violations (PDQ5 option). The mean DSST score in patients with MDD in our study (51) was similar to that reported 
in Chinese $(50,7)$ and Japanese patients with MDD $(54,3)$ before starting antidepressant therapy, but higher than in comparable populations in the US and Europe (42.0 in the FOCUS study and 43,1 in the CONNECT study) $[18,19,36,37]$. This may partially reflect cultural differences between different geographical populations.

Separately, it should be noted that significant differences between the MDD group and HC, found during the performance of objective cognitive tests, were maintained for each age category, despite the general trend of deterioration of cognitive performance with age (table 4 ). It is important to emphasize that in our study the HC performed all RAVLT subtests with better results than proposed metanorms by Schmidt [29]. This pattern was also observed in all age groups $\mathrm{HC}$ in the results of DSST [35].

Table 4

Performance of cognitive tests in different age groups

\begin{tabular}{|c|c|c|c|c|c|c|c|c|c|c|}
\hline \multirow{3}{*}{ Cognitive test } & \multicolumn{10}{|c|}{ Age groups, years } \\
\hline & \multicolumn{2}{|c|}{ 18-29 } & \multicolumn{2}{|c|}{$30-39$} & \multicolumn{2}{|c|}{$40-49$} & \multicolumn{2}{|c|}{$50-59$} & \multicolumn{2}{|c|}{$60-69$} \\
\hline & $\begin{array}{c}\text { MDD } \\
\mathrm{n}=32\end{array}$ & $\begin{array}{c}\text { HC } \\
n=22\end{array}$ & $\begin{array}{l}\text { MDD } \\
\mathrm{n}=\mathbf{4 5}\end{array}$ & $\begin{array}{c}\text { HC } \\
n=25\end{array}$ & $\begin{array}{l}\text { MDD } \\
n=27\end{array}$ & $\begin{array}{c}\text { HC } \\
n=15\end{array}$ & $\begin{array}{l}\text { MDD } \\
\mathrm{n}=18\end{array}$ & $\begin{array}{c}\text { HC } \\
n=8\end{array}$ & $\begin{array}{l}\text { MDD } \\
\mathrm{n}=8\end{array}$ & $\begin{array}{c}\text { HC } \\
\mathrm{n}=5\end{array}$ \\
\hline $\begin{array}{l}\text { RAVLT } \\
\text { immediate recall }\end{array}$ & $\begin{array}{c}50,06 \\
(7,54)^{*}\end{array}$ & $\begin{array}{l}61,10 \\
(7,56)\end{array}$ & $\begin{array}{c}49,77 \\
(7,63) *\end{array}$ & $\begin{array}{l}65,40 \\
(6,83)\end{array}$ & $\begin{array}{c}50,33 \\
(6,41) *\end{array}$ & $\begin{array}{l}63,33 \\
(5,27)\end{array}$ & $\begin{array}{l}47,47 \\
(8,22)\end{array}$ & $\begin{array}{l}53,13 \\
(7,77)\end{array}$ & $\begin{array}{c}40,13 \\
(7,57) *\end{array}$ & $\begin{array}{l}57,00 \\
(7,14)\end{array}$ \\
\hline $\begin{array}{l}\text { RAVLT proactive } \\
\text { interference score }\end{array}$ & $\begin{array}{c}6,58 \\
(1,39)^{*}\end{array}$ & $\begin{array}{c}7,81 \\
(1,83)\end{array}$ & $\begin{array}{c}5,91 \\
(1,22)^{*}\end{array}$ & $\begin{array}{c}7,80 \\
(1,76)\end{array}$ & $\begin{array}{c}5,79 \\
(1,62) *\end{array}$ & $\begin{array}{c}8,00 \\
(2,00)\end{array}$ & $\begin{array}{c}5,48 \\
(1,17)\end{array}$ & $\begin{array}{c}5,75 \\
(1,67)\end{array}$ & $\begin{array}{c}5,25 \\
(1,83)\end{array}$ & $\begin{array}{c}7,20 \\
(2,68)\end{array}$ \\
\hline $\begin{array}{l}\text { RAVLT retroactive } \\
\text { interference score }\end{array}$ & $\begin{array}{c}10,90 \\
(2,50)^{*}\end{array}$ & $\begin{array}{l}13,43 \\
(2,32)\end{array}$ & $\begin{array}{c}10,82 \\
(2,59) *\end{array}$ & $\begin{array}{l}14,48 \\
(1,05)\end{array}$ & $\begin{array}{c}10,92 \\
(2,64) *\end{array}$ & $\begin{array}{l}14,33 \\
(0,90)\end{array}$ & $\begin{array}{c}10,00 \\
(2,21) *\end{array}$ & $\begin{array}{l}12,63 \\
(2,56)\end{array}$ & $\begin{array}{c}8,25 \\
(2,12) *\end{array}$ & $\begin{array}{l}12,40 \\
(2,61)\end{array}$ \\
\hline $\begin{array}{l}\text { RAVLT } \\
\text { delayed recall score }\end{array}$ & $\begin{array}{c}11,10 \\
(2,94)^{*}\end{array}$ & $\begin{array}{l}13,86 \\
(2,10)\end{array}$ & $\begin{array}{c}11,07 \\
(2,39) *\end{array}$ & $\begin{array}{l}14,40 \\
(1,32)\end{array}$ & $\begin{array}{c}10,92 \\
(2,19) *\end{array}$ & $\begin{array}{l}14,53 \\
(0,92)\end{array}$ & $\begin{array}{l}10,00 \\
(2,76)\end{array}$ & $\begin{array}{l}12,38 \\
(3,02)\end{array}$ & $\begin{array}{c}7,63 \\
(2,50) *\end{array}$ & $\begin{array}{l}12,40 \\
(1,52)\end{array}$ \\
\hline $\begin{array}{l}\text { RAVLT } \\
\text { delayed recognition }\end{array}$ & $\begin{array}{l}14,30 \\
(1,29)\end{array}$ & $\begin{array}{l}14,81 \\
(0,68)\end{array}$ & $\begin{array}{c}14,27 \\
(0,10) *\end{array}$ & $\begin{array}{l}14,96 \\
(0,20)\end{array}$ & $\begin{array}{c}14,33 \\
(0,87)^{*}\end{array}$ & $\begin{array}{l}14,80 \\
(0,56)\end{array}$ & $\begin{array}{l}12,84 \\
(4,66)\end{array}$ & $\begin{array}{l}14,50 \\
(1,07)\end{array}$ & $\begin{array}{l}13,50 \\
(1,69)\end{array}$ & $\begin{array}{l}15,00 \\
(0,00)\end{array}$ \\
\hline TMT-B & $\begin{array}{c}71,03 \\
(18,37)\end{array}$ & $\begin{array}{c}62,67 \\
(18,70)\end{array}$ & $\begin{array}{c}73,00 \\
(24,18) *\end{array}$ & $\begin{array}{c}50,52 \\
(21,08)\end{array}$ & $\begin{array}{c}77,76 \\
(17,36) *\end{array}$ & $\begin{array}{c}57,21 \\
(18,78)\end{array}$ & $\begin{array}{c}90,37 \\
(29,91) \%\end{array}$ & $\begin{array}{c}68,00 \\
(12,17)\end{array}$ & $\begin{array}{c}98,25 \\
(30,87)\end{array}$ & $\begin{array}{c}71,80 \\
(17,51)\end{array}$ \\
\hline DSST & $\begin{array}{c}56,41 \\
(9,27)^{*}\end{array}$ & $\begin{array}{c}63,05 \\
(12,50)\end{array}$ & $\begin{array}{c}52,61 \\
(10,86)^{*}\end{array}$ & $\begin{array}{c}68,00 \\
(13,34)\end{array}$ & $\begin{array}{c}47,73 \\
(10,70) *\end{array}$ & $\begin{array}{l}60,00 \\
(9,12)\end{array}$ & $\begin{array}{c}42,32 \\
(11,55)^{*}\end{array}$ & $\begin{array}{l}54,13 \\
(8,15)\end{array}$ & $\begin{array}{c}39,88 \\
(10,04)\end{array}$ & $\begin{array}{l}45,80 \\
(6,91)\end{array}$ \\
\hline \multicolumn{11}{|c|}{ Results of DSST presented as median (upper-lower quartile) } \\
\hline DSST & $\begin{array}{c}57 \\
(53-63)\end{array}$ & $\begin{array}{c}62 \\
(54-71)\end{array}$ & $\begin{array}{c}51 \\
(45-60)\end{array}$ & $\begin{array}{c}68 \\
(62-73)\end{array}$ & $\begin{array}{c}48 \\
(39-53)\end{array}$ & $\begin{array}{c}61 \\
(56-67)\end{array}$ & $\begin{array}{c}41 \\
(33-56)\end{array}$ & $\begin{array}{c}53 \\
(48-61)\end{array}$ & $\begin{array}{c}40 \\
(33-49)\end{array}$ & $\begin{array}{c}47 \\
(39-52)\end{array}$ \\
\hline
\end{tabular}

Note: data are presented as means (SD) unless otherwise stated;* - $<0,05$ according to T-test for independent samples

Afterward, using ROC analysis, we assessed the discriminatory ability of different cognitive tests for separating patients with MDD from healthy individuals by the scores of cognitive tests (table 5). The analysis was performed only for those tests, the performance of which by patients with an active DE was significantly worse according to the available normative data. The PDQ-5 test had an excellent quality of a model for differentiating patients with MDD from $\mathrm{HC}$ in the total sample, a total score of $\mathrm{PDQ}-5>3,5$ provided the opportunity to separate patients with MDD from $\mathrm{HC}$ with a sensitivity of $90 \%$ and specificity of $91 \%$. The RAVLT subtest for immediate recall had a very good diagnostic value for differentiating patients with MDD throughout the sample, the threshold score of the subtest $<56,5$ words had a sensitivity of $85 \%$ and a specificity of $82 \%$ for the separation of patients with MDD from HC in the general sample. The RAVLT subtest for proactive interference showed good diagnostic value for separating patients with MDD from $\mathrm{HC}$ in the entire sample, the subtest threshold $<6,5$ words with a sensitivity of $66 \%$ and a specificity of $72 \%$ separated patients with MDD from HC. The RAVLT subtest for retroactive interference had a very good diagnostic value for predicting MDD in the entire sample, a subtest threshold level $<13,5$ words with optimal sensitivity and specificity of $86 \%$ and $76 \%$, respectively, to separate healthy individuals from patients with MDD.

The TMT-B test demonstrated good diagnostic value for the separation of patients with MDD in the entire sample, the threshold level of test performance $>63 \mathrm{~s}$ had optimal sensitivity $(70 \%)$ and specificity $(68 \%)$ for the separation of healthy individuals from patients with MDD. The DSST test showed good diagnostic value for predicting MDD in the entire sample, the test score $<58,5$ had optimal sensitivity and specificity $(74 \%$ and $63 \%)$ to separate healthy individuals from patients with MDD. To the best of our knowledge, we were the first to obtain cutoff scores of those neuropsychological tests for discrimination MDD patients from HC. 
Table 5

Discriminative validity of cognitive tests in the Ukrainian MDD patients

\begin{tabular}{|c|c|c|c|c|c|c|}
\hline Age (years) & AUC & $95 \%$ CI & $\mathbf{P}$ & Cutoff scores & Sensitivity & Specificity \\
\hline \multicolumn{7}{|c|}{ PDQ-5 total score } \\
\hline Whole sample & $0,947 \pm 0,015$ & $0,918-0,977$ & $<0,0001$ & $>3,5$ & $90 \%$ & $91 \%$ \\
\hline $18-24$ & $0,977 \pm 0,025$ & $0,929-1,000$ & $<0,0001$ & $>3,5$ & $100 \%$ & $83 \%$ \\
\hline $25-34$ & $0,954 \pm 0,024$ & $0,908-1,000$ & $<0,0001$ & $>3,5$ & $93 \%$ & $89 \%$ \\
\hline $35-44$ & $0,913 \pm 0,041$ & $0,833-0,994$ & $<0,0001$ & $>2,5$ & $89 \%$ & $83 \%$ \\
\hline $45-54$ & $0,982 \pm 0,017$ & $0,948-1,000$ & $<0,0001$ & $>2,5$ & $100 \%$ & $84 \%$ \\
\hline $55-65$ & $0,942 \pm 0,050$ & $0,845-1,000$ & 0,003 & $>3,0$ & $90 \%$ & $100 \%$ \\
\hline \multicolumn{7}{|c|}{ RAVLT immediate recall (number of words) } \\
\hline Whole sample & $0,875 \pm 0,026$ & $0,825-0,926$ & $<0,0001$ & $<56,5$ & $85 \%$ & $82 \%$ \\
\hline $18-24$ & $0,831 \pm 0,094$ & $0,646-1,000$ & 0,009 & $<57$ & $100 \%$ & $73 \%$ \\
\hline $25-34$ & $0,895 \pm 0,038$ & $0,820-0,970$ & $<0,0001$ & $<59,5$ & $85 \%$ & $70 \%$ \\
\hline $35-44$ & $0,956 \pm 0,031$ & $0,894-1,000$ & $<0,0001$ & $<59,5$ & $91 \%$ & $83 \%$ \\
\hline $45-54$ & $0,800 \pm 0,074$ & $0,656-0,945$ & 0,001 & $<57,5$ & $86 \%$ & $74 \%$ \\
\hline $55-65$ & $0,935 \pm 0,065$ & $0,807-1,000$ & 0,004 & $<53,5$ & $94 \%$ & $80 \%$ \\
\hline \multicolumn{7}{|c|}{ RAVLT proactive interference (number of words) } \\
\hline Whole sample & $0,738 \pm 0,039$ & $0,662-0,814$ & $<0,0001$ & $<6,5$ & $66 \%$ & $72 \%$ \\
\hline $18-24$ & $0,616 \pm 0,123$ & $0,375-0,856$ & 0,36 & - & - & - \\
\hline $25-34$ & $0,758 \pm 0,066$ & $0,628-0,888$ & $<0,0001$ & $<7,5$ & $83 \%$ & $63 \%$ \\
\hline $35-44$ & $0,795 \pm 0,089$ & $0,621-0,970$ & 0,003 & $<6,5$ & $70 \%$ & $75 \%$ \\
\hline $45-54$ & $0,696 \pm 0,087$ & $0,525-0,867$ & 0,03 & $<6,5$ & $72 \%$ & $74 \%$ \\
\hline $55-65$ & $0,694 \pm 0,119$ & $0,462-0,927$ & 0,20 & - & - & - \\
\hline \multicolumn{7}{|c|}{ RAVLT retroactive interference (number of words) } \\
\hline Whole sample & $0,855 \pm 0,029$ & $0,797-0,913$ & $<0,0001$ & $<13,5$ & $86 \%$ & $76 \%$ \\
\hline $18-24$ & $0,690 \pm 0,121$ & $0,452-0,928$ & 0,13 & - & - & - \\
\hline $25-34$ & $0,900 \pm 0,039$ & $0,823-0,976$ & $<0,0001$ & $<13,5$ & $85 \%$ & $89 \%$ \\
\hline $35-44$ & $0,945 \pm 0,034$ & $0,877-1,000$ & $<0,0001$ & $<13,5$ & $82 \%$ & $92 \%$ \\
\hline $45-54$ & $0,795 \pm 0,073$ & $0,652-0,939$ & 0,001 & $<13,5$ & $82 \%$ & $74 \%$ \\
\hline $55-65$ & $0,841 \pm 0,129$ & $0,589-1,000$ & 0,023 & $<12,5$ & $94 \%$ & $80 \%$ \\
\hline \multicolumn{7}{|c|}{ TMT-B (time of completion, s) } \\
\hline Whole sample & $0,751 \pm 0,036$ & $0,681-0,822$ & $<0,0001$ & $>63$ & $70 \%$ & $68 \%$ \\
\hline $18-24$ & $0,814 \pm 0,098$ & $0,622-1,000$ & 0,01 & $>61$ & $91 \%$ & $64 \%$ \\
\hline $25-34$ & $0,673 \pm 0,069$ & $0,539-0,808$ & 0,02 & $>58,5$ & $73 \%$ & $60 \%$ \\
\hline $35-44$ & $0,919 \pm 0,040$ & $0,841-0,997$ & $<0,0001$ & $>58,0$ & $83 \%$ & $83 \%$ \\
\hline $45-54$ & $0,667 \pm 0,087$ & $0,497-0,836$ & 0,07 & - & - & - \\
\hline $55-65$ & $0,821 \pm 0,116$ & $0,594-1,000$ & 0,03 & $>71,5$ & $90 \%$ & $80 \%$ \\
\hline \multicolumn{7}{|c|}{ DSST (number of correct symbols) } \\
\hline Whole sample & $0,747 \pm 0,036$ & $0,676-0,817$ & $<0,0001$ & $<58,5$ & $74 \%$ & $63 \%$ \\
\hline $18-24$ & $0,645 \pm 0,132$ & $0,386-0,903$ & 0,25 & - & - & - \\
\hline $25-34$ & $0,755 \pm 0,060$ & $0,638-0,873$ & $<0,0001$ & $<59,5$ & $71 \%$ & $67 \%$ \\
\hline $35-44$ & $0,867 \pm 0,051$ & $0,767-0,967$ & $<0,0001$ & $<60,5$ & $78 \%$ & $83 \%$ \\
\hline $45-54$ & $0,739 \pm 0,079$ & $0,584-0,893$ & 0,01 & $<53,5$ & $68 \%$ & $72 \%$ \\
\hline $55-65$ & $0,695 \pm 0,117$ & $0,465-0,924$ & 0,19 & - & - & - \\
\hline
\end{tabular}

\section{CONCLUSIONS}

1. Patients with an active episode of MDD demonstrate as subjective as objective cognitive 12 impairments as compared to HC.

2. Cognitive dysfunction in the Ukrainian cohort of MDD patients is characterized by mild 
impairments of working memory; moderate impairments in alternating attention; and moderate impairments in executive functioning

3. PDQ-5 and neuropsychological tests, such as RAVLT (subtests for immediate recall, proactive and retroactive interference), TMT-B, and DSST show from excellent to good diagnostic value for separating patients with MDD from HC

4. PDQ-5, RAVLT, TMT-B, and DSST and obtained age-adjusted cutoffs of those tests could be used by clinicians in everyday practice to assess the presence of cognitive dysfunction in MDD patients as a method to secure a more valid assessment of cognitive impairments specific to these patients

Conflict of Interest Statement. The authors declare that the research was conducted in the absence of any commercial or financial relationships that could be construed as a potential conflict of interest.

\section{REFERENCES}

1. Smith K. Mental health: a world of depression. Nature. 2014 Nov 13; 515 (7526): 181.

2. Kessler RC, Bromet EJ. The epidemiology of depression across cultures. Annu Rev Public Health. 2013; 34: 119-38.

3. Krol M, Koopmanschap M, Papenburg J, et al. Do productivity costs matter?: the impact of including productivity costs on the incremental costs of interventions targeted at depressive disorders. Pharmacoeconomics. 2011 Jul; 29 (7): 601-19.

4. McIntyre RS, Soczynska JZ, Woldeyohannes HO, et al. The impact of cognitive impairment on perceived workforce performance: results from the International Mood Disorders Collaborative Project. Compr Psychiatry. 2015 Jan; 56: 279-82.

5. Conradi HJ, Ormel J, de Jonge P. Presence of individual (residual) symptoms during depressive episodes and periods of remission: a 3-year prospective study. Psychol Med. 2011 Jun; 41 (6): 1165-74.

6. Maruff $\mathrm{P}$, Jaeger J. Understanding the importance of cognitive dysfunction and cognitive change in major depressive disorder. In: McIntyre $\mathrm{R}$, editor. Cognitiveimpairmentin major depressive disorder: Clinical relevance, biological substrates, and treatment opportunities. Cambridge: Cambridge University Press; 2016.15-29p.

7. Cambridge OR, Knight MJ, Mills N, et al. The clinical relationship between cognitive impairment and psychosocial functioning in major depressive disorder: A systematic review. Psychiatry Res. 2018 Nov; 269: 157-71.

8. Jaeger J, Zaragoza S. The digit symbol substitution test (DSST): psychometric properties and clinical utility in major depressive disorder. Eur Neuropsychopharmacol. 2016 Oct; 26 (2): 341p.

9. Baune BT, Air T. Clinical, Functional, and Biological Correlates of Cognitive Dimensions in Major Depressive Disorder - Rationale, Design, and Characteristics of the Cognitive Function and Mood Study (CoFaM-Study). Front Psychiatry. 2016 Aug 26; 7: 150p.
10. Belgaied W, Samp J, Vimont A, etal. Routine clinical assessment of cognitive functioning in schizophrenia, major depressive disorder, and bipolar disorder. Eur Neuropsychopharmacol. 2014 Jan; 24 (1): 133-41.

11. Lee RS, Hermens DF, Porter MA, et al. A meta-analysis of cognitive deficits in first- episode major depressive disorder. J Affect Disord. 2012; 140 (2): 113-24.

12. Snyder HR. Major depressive disorder is associated with broad impairments on neuropsychological measures of executive function: a meta-analysis and review. Psychol Bull. 2013 Jan;139 (1): 81-132.

13. Rock PL, Roiser JP, Riedel WJ, et al. Cognitive impairment in depression: a systematic review and meta-analysis. Psychol Med. 2014 Jul; 44 (10): 2029-40.

14. Egeland J, Lund A, Landrø NI, et al. Cortisol level predicts executive and memory function in depression, symptom level predicts psychomotor speed. Acta Psychiatr Scand. 2005 Dec; 112 (6): 434-41.

15. Hammar A, Ardal G. Cognitive functioning in major depression - a summary. Front Hum Neurosci. 2009 Sep 25; 3: 26.

16. Reppermund S, Ising $M$, Lucae $S$, et al. Cognitive impairment in unipolar depression is persistent and non-specific: further evidence for the final common pathway disorder hypothesis. Psychol Med. 2009 Apr; 39 (4): 603-14.

17. Shilyansky C, Williams L, Gyurak A, et al. Effect of antidepressant treatment on cognitive impairments associated with depression: a randomised longitudinal study. Lancet Psychiatry. 2016 May; 3 (5): 425-35.

18. Sumiyoshi T, Watanabe K, Noto S, et al. Relationship of cognitive impairment with depressive symptoms and psychosocial function in patients with major depressive disorder: cross-sectional analysis of baseline data from PERFORM-J. J Affect Disord. 2019; 258: 172-78.

19. Wang G, Tan KHX, Ren H, et al. Impact of Cognitive Symptoms on Health-Related Quality of 
Life and Work Productivity in Chinese Patients with Major Depressive Disorder: Results from the PROACT Study. Neuropsychiatr Dis Treat. 2020 Mar 13; 16: 749-759.

20. American Psychiatric Association. Diagnostic and Statistical Manual of Mental Disorders. 5th ed. Arlington: American Psychiatric Association; 2013. 947 p.

21. Levada OA, Troyan AS. Cognitivefunctional relationships in major depressive disorder: Crucial data from a Ukrainian open-label study of vortioxetine versus escitalopram. J Affect Disord. 2019 May 1; 250: 114-122.

22. Montgomery SA, Asberg M. A new depression scale designed to be sensitive to change. Br J Psychiatry. 1979; 134: 382-9.

23. Guy W. Clinical Global Impressions. In: Guy W, editor. ECDEU Assessment Manual for Psychopharmacology Revised. Rockville: National Institute of Mental Health; 1976. 217-222p.

24. Cha D. Perceived Deficits Questionnaire Depression, 5-item (PDQ-D-5). In: McIntyre R, editor. Cognitive impairment in major depressive disorder: Clinical relevance, biological substrates, and treatment opportunities. Cambridge: Cambridge University Press; 2016. P. 242-56.

25. Strauss E, Sherman EMS, Spreen O. A compendium of neuropsychological tests: Administration, norms, and commentary. 3rd Edition. Oxford, England: Oxford University Press; 2006. $1216 \mathrm{p}$.

26. Harrison JE, Barry H, Baune BT, et al. Stability, reliability, and validity of the THINCit screening tool for cognitive impairment in depression: A psychometric exploration in healthy volunteers. Int J Methods Psychiatr Res. 2018 Sep; 27 (3): e1736.

27. Maj M, D'Elia L, Satz P, et al. Evaluation of two new neuropsychological tests designed to minimize cultural bias in the assessment of HIV1 seropositive persons: a WHO study. Arch Clin Neuropsychol. 1993 Mar;8 (2): 123-35.

28. Reitan RM, Wolfson D. The HalsteadReitan Neuropsycholgical Test Battery: Therapy and clinical interpretation. Tucson, AZ: Neuropsychological Press. 1985. 486 p.

29. Schmidt M. Rey Auditory Verbal Learning Test: RAVLT: a Handbook. Los Angeles, CA: Western Psychological Services; 1996. 139 p.

30. Ahern E, Semkovska M. Cognitive functioning in the first-episode of major depressive disorder: A systematic review and meta-analysis. Neuropsychology. 2017 Jan; 31 (1): 52-72.

31. McIntyre RS, Florea I, Tonnoir B, et al. Efficacy of vortioxetine on cognitive functioning in working patients with major depressive disorder. J Clin Psychiatry. 2017 Jan;78 (1): 115-21.

32. Cabanel N, Schmidt AM, Fockenberg S, et al. Evening preference and poor sleep independently affect attentional-executive functions in patients with depression. Psychiatry Res. 2019 Nov; 281:112533.

33. Klojčnik M, Kavcic V, Bakracevic Vukman K. Relationship of Depression With Executive Functions and Visuospatial Memory in Elderly. Int J Aging Hum Dev. 2017 Dec; 85 (4): 490-503.

34. Rajtar-Zembaty A, Rajtar-Zembaty J, Olszewska $\mathrm{K}$, et al. Comparison of cognitive functioning of elders with late-life depression and patients with and without a history of depressive episodes: a cross-sectional study. Psychol Health Med. 2020 Dec 22: 1-7.

35. Kiely KM, Butterworth P, Watson N, et al. The Symbol Digit Modalities Test: Normative data from a large nationally representative sample of Australians. Arch Clin Neuropsychol. 2014; 29 (8): 767-775.

36. McIntyre RS, Lophaven S, Olsen CK. A randomized, double-blind, placebo-controlled study of vortioxetine on cognitive function in depressed adults. Int $\mathrm{J}$ Neuropsychopharmacol. 2014 Oct; 17 (10): 1557-67.

37. Mahableshwarkar AR, Zajecka J, Jacobson W, et al. A randomized, placebocontrolled, active-reference, double-blind, flexibledose study of the efficacy of vortioxetine on cognitive function in major depressive disorder. Neuropsychopharmacology. 2015 Jul; 40 (8): 2025-37. 